\title{
1. Introduction to development in China, India, and Japan
}

\section{WHAT IS DEVELOPMENT?}

Development economics examines the economics of the developing world, or countries with low and middle levels of income. The gap between the developing and developed world is large in terms of both levels of income and various measures of living standards. The concept of development has evolved over time, from one of measuring gross domestic product (GDP) per capita, to one that takes into account a variety of other measures, such as health and education, and institutions.

Societies choose development trajectories based upon political conditions, availability of natural resources, characteristics of the population, geography, and other factors. The outcomes of development policies in different contexts vary wildly, and countries that follow the same policies do not necessarily end up at the same level of development. For example, structural adjustment programs implemented in developing countries to encourage privatization, trade and financial liberalization, and deregulation often resulted not in economic development, but in various stages of economic degradation, including crisis.

A concerted economic development program may include programs to stimulate industrialization, service expansion, trade, infrastructure, education, health, social services, and more. Development occurs as GDP per capita and well-being are raised, access to goods and services is improved, and individuals have more capacity to pursue their life goals. It often includes knowledge transfer, increase in productive efficiency, encouragement of innovation, increase in skilled labor, reduced costs of doing business, increased foreign investment, and improved access to medicine and medical technology. Development may or may not occur under a concerted reform program, under different types of political regimes.

Increasingly, the term "sustainable development" is also used to describe an economic, environmental, and social system that is reproducible. While not synonymous with economic development per se, sustainable development takes a fashionable holistic approach to development, stressing that economic activity must strive to be environmentally and socially friendly. 
Changing definitions of development has influenced development theory. Development theory was used in earnest after World War II to better understand how South-Eastern European countries and newly independent colonies could develop. Countries remaining in poverty were said to be caught in a vicious circle of poverty and low productivity that required a clear plan to resolve. Theory seeks to explain how countries grow, and how they can overcome the vicious circle. The "big push" theory and its ilk emphasized that concerted policy focus in several areas, or across several industries, was necessary to end low levels of employment, investment, demand, and skills formation at the center of the vicious circle.

Theory has also explained how policies that are successful in one country may not be successful in another. For example, convergence theories assumed that developing countries would converge to the standard of living that developed countries held, but this has rarely occurred in history. There are several strains of convergent as well as non-convergent economic development theory that reflect the struggle to understand development trajectories and development policy, which I explore in Chapter 3. Convergent theories include those supporting the absolute, conditional, and club convergence hypotheses that predicted convergence under varying conditions. While convergence theories were seriously considered through the 1990s, they were ultimately displaced by theories of non-convergence. In particular, economists such as Pritchard (1997) stress that rather than convergence, divergence occurred between developed and developing countries from 1870 to 1990.

Non-convergence theories include theories that emphasize expectations and multiple equilibria, that society can end up in a variety of development levels depending on what individuals have an incentive to do; theories of aspiration gaps, in which society may end up at a low level of development if individuals do not aspire to more; theories of history dependence, in which low levels of development are perpetuated through history; and theories of institutions, where particular organizations or practices influence economic development (Ray 2008).

Contemporary development economics has favored empirics over theory, examining data and case studies to support proposed development policies, but both empirics and theory have proven central to understanding development trajectories and associated policies. Using theory alone, one can bypass reality and end up with an idea of the way development arises that misses critical aspects of the situation. On the other hand, one can use empirical data to examine relationships between variables, but this does not necessarily present a clear understanding of the big picture (Bardhan 2005). Both are necessary in order to understand how and explain why an economic develops as it does. 
Although economists do not agree on the "right" mix of theory and empiricism, most development economists have accepted the once revolutionary idea that economic development is about more than increasing GDP or GDP per capita. The idea that development was more than economic growth is rooted in academic research of the 1970s. Gunnar Myrdal, a Nobel prize-winning economist, emphasized that development embodies the "upward movement of the entire social system," including not only economic factors and particularly production, but also consumption across all levels of society, health, education, all institutions, and the generation of progressive attitudes (Myrdal 1974). Myrdal importantly viewed production and distribution as interrelated, with more equitable distribution improving production, and production boosting the income distributed. Later, economists added to this the notions of improving capabilities of individuals (Amartya Sen) and focused on additional criteria for well-being, such as environmental sustainability and gender equality.

Focus in the 1980s and 1990s upon privatization, liberalization, and deregulation ran contrary to Myrdal's development perspective. Myrdal asserted that equality is an essential aspect of economic development, rather than an afterthought that should be carried out through redistribution of income. But so-called Washington Consensus policies focused on economic growth by country, even if few citizens were enriched, rather than improvements in living standards for the masses. The Washington Consensus period posed a challenge for developing countries that were attempting to combat low levels of living. Washington Consensus policies were aggressively promoted by the International Monetary Fund (IMF) and World Bank, and backed vigorously by the United States. These policies exacerbated adverse economic conditions experienced in developing countries throughout the world. For example, as South Korea experienced high corporate debt-to-equity ratios during the Asian financial crisis, the capital market opening required under the Washington Consensus increased South Korea's external debt to more than one-third of Korean GDP (McCleery and De Paolis 2008).

Later in the Washington Consensus period, in response to poor outcomes resulting from Washington Consensus policies, leading scholars such as Joseph Stiglitz and Amartya Sen reiterated Myrdal's sentiment about human-focused development. Myrdal's view of development, embodied in the work of development experts for some time, had been quashed by financial interests; so much so that in the late 1990s, the revival of human-focused development was as revolutionary as it had been in Myrdal's time. Hoff and Stiglitz (2001) wrote that "market economies do not 'naturally' make the right trade-offs." Sen emphasized that human 
capabilities matter. He focused on freedom of choice as an essential component of quality of life.

What is more, China's rise to power in the 1990s underscored the fact that sudden liberalization under Washington Consensus policies was not necessary for economic development. China was able to lift more than 500 million people out of poverty (World Bank 2014) while very selectively and slowly opening to the outside world. Because China was more insulated against external financial flows, China also emerged from the Asian financial crisis relatively unscathed. Even today, China remains closed to large financial flows, and state-owned banks and enterprises persist.

In the 1990s and 2000s, the field of development devoted its focus to capabilities and institutions. Economies that possessed institutions such as property rights, rule of law including legal protections for creditors, democratic political institutions, and low levels of corruption appeared to some economists to do better. Institutions could reduce transaction costs. It seemed that progress could be made. Countries such as South Korea, which took up the above institutions, were held up as examples of "getting institutions right." The impact of strong formal and informal institutions on economic development was believed to surmount barriers to development, and provided the backdrop against which policy changes could be effective.

The 2008 financial crisis that stemmed from extensive financial institutions' holdings of new types of mortgage-backed assets began the reversal of development in many countries, including China, India, and Japan. All three countries worked to stem the crisis.

\section{ASIAN DEVELOPMENT}

Economists have asked many times whether there is a specific strain of Asian development. During the 1990s, the South-East Asian nations of Thailand, Indonesia, South Korea, Malaysia, Singapore, the Philippines, and Hong Kong experienced a dramatic economic boom that was referred to as the "Asian economic miracle." Lessons drawn from growth of the Asian Tigers before the Asian financial crisis asserted that macroeconomic performance, high savings rates, strong education, and openness to foreign technology were important.

However, the proper combination of growth ingredients remained elusive, even for the Asian miracle countries. Stanley Fischer of the IMF wrote in 1996: "[An] important point on East Asia ... is that there is almost no generalization that applies to every fast-growing country in East Asia, not even the fact of very high rates of investment and saving, where 
Hong Kong is the exception." Growth cannot be merely attributed to high rates of savings. Fischer also notes that the experiences of Malaysia, Indonesia and Thailand are particularly encouraging since they lack previous growth histories.

Despite the fact that no specific recipe for growth could be found for the Asian Tiger, economists have continued to search for one. Other sets of Asian economies have also reinforced the notion of an Asian development model. Kuznets (1994) characterizes East Asian development as shifting workers from agriculture to industry, expanding exports, and providing competitive labor markets due to surplus populations. Drawing on the experiences of Japan, South Korea, and Taiwan, Kuznets describes the industrialization process as being influenced by "developmental" or interventionist governments that intentionally accelerate the growth rate. These economies were unusually successful in raising the growth rate and therefore are of special significance. Park (1990) looks at the experiences of South Korea and Taiwan, which have common structural characteristics and export-led industrialization processes. Park emphasizes the key role of government in bringing growth about, whether under a leading role in Korea or in a supportive role in Taiwan. The ongoing presence of growth in China and India and the history of growth in Japan creates an interesting study, and we examine the concerted reform trajectories or intentional growth periods in each of these countries.

\section{ECONOMIC REFORM}

A period of economic reform is a time of accelerated development; one that is intentionally undertaken by policy makers, that is timely in its appearance, and that places emphasis on loci of comparative advantage. Often it is initiated as a response to economic repression or perceived economic weakness. It is defined by a clear break, in one or more ways, from business as usual, and may be led by a strong leader and/or group of economically progressive individuals.

The economic reform process is also timely in its appearance, in the sense that the policies that are implemented are viewed as necessary to further economic development, and also in relation to the external environment. The reform process may require more caution, for example, in an extremely competitive global environment. The process may require more extensive changes in the face of impending crisis.

Economic reform underscores a country's comparative advantage, or production at its lowest opportunity cost. Economic policies have been shown to fail when they hinge upon a development process that is 
unnatural or external to a nation. When a country's comparative advantage is incorporated into the reform program, economic development stands a better chance of becoming self-sustaining.

A country's reform strategy is unique in what programs are undertaken, and in which order. Stages or tiers of reform can be used to classify different time periods of the unique reform process, with Tier One introducing basic reforms, Tier Two representing more enhanced reforms, and Tier Three displaying advanced reforms. The reason for tiered reform within a successful reform program is that development policies must necessarily change as an economy develops, since various levels of financial, physical, and human investment, as well as institutions at different stages of development, are available. We have seen in practice that "big bang" reforms often lead to financial crisis or incomplete progress. Therefore, although reform "tiers" are rarely so clearly defined at the time of reform, they can be used to generally classify reform policy measures.

While there is no handbook or prescription to reform, Tier One reforms may include agricultural reform, an improved tax system, and a basic health and education system, in order to build basic human capital and reproductive capabilities, and to establish funds for the government to embark on the reform process. Light industry development and some trade may occur to create an economic base for further growth. Tier Two reforms may include development of light industry, a financial system, a more sophisticated trade regime, and a better educational system. Tier Three reforms may implement heavy industry or more technology-infused manufacturing, a services industry, a more complex financial system, and more open trade. This type of progression is reflected to a large degree in the reform trajectories of China and Japan in particular. We now provide a general overview of the reform processes in China, India, and Japan.

\section{PERSPECTIVES ON REFORM IN CHINA, INDIA, AND JAPAN}

China, India, and Japan are all strong examples of economic growth. Growth took place as a result of new policies, and institutions were put in place. These were a clear break with the past and instilled purposely, to foment growth.

Economic reform began in China in 1979 at the Third Plenum, where Deng Xiaoping took power. Reform began as a response to the stilted economic progress over the period of Mao Zedong's tyrannical rule. From a closed, command economy, China became an open, dominantly market economy by the year 2000. The transition was gradual but dramatic, 
affecting every citizen, rural and urban. Leaders first set out to reform the agricultural sector, changing from communal farming to own-plot farming. Some freeing up of township and village enterprises in rural areas from state control allowed them to produce for market demand, turning a profit for some. Marketization took hold more fiercely, and China indeed became the world's factory. China's accession to the World Trade Organization in 2001 and its increasingly dominant position in the global economy sealed its status as one of the most successful growth stories of all time.

In India, economic reform started in due course. State-owned enterprises in urban areas were given market incentives and were allowed to enjoy some autonomy. Reform began in India at independence in 1947, when India became a democracy and a planned economy. India embarked on a path of capital accumulation and industrialization, which succeeded during the earlier years but faltered in the late 1960s and early 1970s, after famines set in. Import substitution industrialization undertaken from independence until the 1990s did not lead to a significant take-off in growth. Growth occurred, but Indian citizens were often untouched by it. India's significant policy reversals in the 1990s, that substantially reduced barriers to trade, led in the late 1990s and early 2000s to the take-off of India's information and communication technology (ICT) service sector.

Japan's reform began in 1868 with the coming of the Meiji Restoration. The Emperor Meiji eliminated the feudal system that had enabled economic stagnation and military weakness. The monetary and fiscal systems were modernized, and the government sought to improve infrastructure and technological knowledge. As Japan's agricultural sector increased in productivity, workers were freed to move to urban areas. Heavy industry expanded in the early twentieth century. After World War I, Japan was provided access to Western technology as an ally of the United States. Trade boomed. Japan's occupation after World War II led to some reversals that were countered by the Allies under the Dodge Plan. Increasing industrialization and export activity, coupled with increasing levels of technological innovation, led to Japan's promotion to developed-country status in the 1970s and 1980s.

How can we put in perspective the comparative development paths of China, India, and Japan? These three countries experienced rapid economic growth, due to changes in economic policy, accumulation of human capital, and improvements in technology. They developed in distinct ways, given their vastly different political systems and economic conditions at the outset of reform. The degree of financial liberalization that the countries allowed has also greatly impacted their level of success.

China, India, and Japan are often used as examples of how development can or should take place. Separating growth success from institutional 
context, however, it is more difficult to tell which policies or patterns are transferable to other countries. China's gradual approach to development was successful, but government control over the economy and capital controls ensured that other plans would not usurp the slow unfolding of development policies. India's success in information and communication technology originated from a coincidence of yet-untapped supply and new demand, when companies began to prepare for the year 2000 (Y2K) by having their computer software scoured for potential bugs when the year changed back to '00. Japan's success rose out of a long process of growthoriented policy and planning.

The relationship between institutions and economic development has been studied in the economics literature in order to shed light on what policies and patterns may be transferable to other countries. In some of the latest research, Acemoglu et al. (2006) distinguish between technology adoption-based strategies of development and innovation-based strategies of growth, in terms of the institutions present. Institutions present were achieved as equilibria in the home economy and were not imposed from outside, and these same institutions likely necessarily changed over the course of development. "Getting institutions right" depends on the "right" institutions for the pre-development economy, which can be transmutable over time to fit an economy progressing through development. In other words, the current thinking in development economics is that development is contextual, and that the success of policies and patterns of development depend on local institutions, which in turn depend on current competitive equilibria, if and where they exist.

This provides us with a contemporary framework to analyze the progression of economic development in China, India, and Japan. We may consider the institutions that were consistently present and important throughout the development process, and how they changed. We can compare these institutions between countries and consider their interaction with policy that propelled the economies into various stages of growth.

Institutions that were in place at the outset of economic reform vary. In China, the People's Bank was transformed from a deposit-holding institution to a central bank in 1983, creating an institution with the ability to control money. Special Economic Zones (SEZs) were set up in 1979-80 to open up trade to the outside world in specific cities. Township and village enterprises were, prior to reform, low-technology firms with little competitiveness; after reform, they were transformed into profitable institutions. The household responsibility system allowed farmers to transition from communal farming to farming of private plots, which vastly increased agricultural productivity. State-owned enterprises continued 
to provide the urban population with employment, housing, and social services.

In Japan, we take the outset of reform to be the Meiji Restoration of 1868, rather than the American Occupation after World War II. The Meiji Restoration set Japan on a path of intentional modernization and economic growth, interrupted only by World War II. The Meiji period is notable for eliminating institutions that had become counterproductive, namely those of the feudal system. With elimination of the feudal system, the country was oriented toward production and industrialization. The institution of private land ownership was an important replacement for tenancy and subjugation, and a critical base for taxation.

In India, the Planning Commission was created at independence to industrialize the economy. As the strategy of capital investment became insufficient for growth, the Planning Commission was itself reformed in the 1990 s to accede to market forces.

Some institutions ushered in a new phase of development after reform was already under way. The Green Revolution, institutionalized in various ways in India, improved agricultural production over the 1970s. The Integrated Rural Development Programme, created in the 1980s, set out to address the poorest of the poor households (Laxminarayan 1990). In India, a rejection of the growth ideology of the first decades of reform, including rejection of "heavy industrialization, self-reliance, the socialist pattern, the public sector and the control of monopolies" (Ghose 1990), necessitated a new wave of reform and hence new institutions.

Japan's Ministry of International Trade and Industry (MITI) was created in 1949 and propelled Japan to its modern level of development. In Francks's (1992) analysis of MITI's predecessor, the Ministry of Commerce and Industry (MCI), the institution had a middling impact on the iron and steel industries, while its reincarnation as MITI was much more successful in bringing about industrialization, due in part to its close relationship with industry.

China is notable for sharply changing some institutions after the reform process began. State-owned enterprises laid off vast numbers of workers as the economy was increasingly privatized. The state-owned sector subsequently shrank. Township and village enterprises lost out to competition from private enterprises during the 1990s and played a much less important role in the economy thereafter. The People's Bank of China was reorganized in 1998 along the lines of the US Federal Reserve Board, becoming more powerful (Naughton 2007).

All of these institutions played critical roles in shaping the reform and growth process in China, India, and Japan. They were institutions that existed at the beginning equilibrium and that transformed to meet with 
successive equilibria. They worked for their home economies; in the case of Japan, innovation was so successful as to push Japan into the realm of a developed country.

\section{INITIAL CONDITIONS AND REFORM}

The three countries of study, China, India, and Japan, began their growth processes intentionally, through guided and targeted economic policies. The growth process was first catalyzed in Japan, during the Meiji Restoration and again during extensive restructuring post-World War II; in China, in response to Western intervention in the nineteenth and early twentieth century, Communism, and the death of Mao Zedong in the late 1970s; and in India, after independence from Britain in 1947 and again with the implementation of structural adjustment reforms in the early 1990s.

These three countries began with different initial conditions. Japan began its modernization period in 1868 during the Meiji Restoration, as a reaction to Western demands. This island country with few natural resources turned for its source of comparative advantage to technological prowess. Since modernization began so early, Japan had time to study Western technology and update its level of technological know-how in time to "catch up" to Western innovations and accompanying standards of living. The Western world was in the process of industrializing; the industrial revolution had just ended, and standards of living were on the rise.

China's and India's legacies of economic repression led to widespread support for a wider availability of products and better living circumstances. Chinese citizens were ready to purchase a wider range of products than the usual drab clothing and basic offerings. They were also interested in earning higher incomes. Indian citizens were also ready, in the 1990s, to put their higher education to use and obtain better opportunities in the ICT services industry or in other industries that received the knock-on effects of increased domestic consumption.

China and India began the process of reform much later than Japan, when Western nations had already reached a relatively high standard of living. Hence there were vastly different global economic conditions in each nation: different political economies, different economic institutions, and varying levels of production. During this period, complex financial products were being offered in developed countries and global financial flows became increasingly volatile. Global consumption also increased, creating a need for production of inexpensive goods and services.

China and India began the reform process after Western countries were 
already industrialized and living in a modern, consumer society. Both countries were able to integrate their growth processes with a globalizing world. China built up its manufacturing sector and generated many types of goods for export to other nations. From 1979, when China was almost entirely closed off to the rest of the world in trade, to 2009, when China was the largest exporter of consumer products in the world, China altered its economic paradigm dramatically to work in concert with the rest of the world.

India did the same; its leading sector in terms of economic transformation, information and communication technology, boomed as global internet and telecommunications technology rapidly developed. India built up its services sector based on the needs of Western businesses. Hence the timing of India's reform process and global conditions were essential to India's growth.

China and India had resources in human capital. First, China and India were both home to vast labor forces, the largest in the world. Second, overseas Chinese and overseas Indians were important in helping nationals establish businesses. Overseas Chinese invested in manufacturing enterprises and helped to establish business connections with corporations from Hong Kong, Taiwan, and the US. Overseas Indians had experience in information technology (IT)-related industries and therefore resident Indians had access to potential clients in the USA and Western Europe, as well as access to high-quality engineers (Arora and Bagde 2010).

Although both China and India attempted economic reform in the 1950s, neither was truly successful until the 1980s or 1990s. Both China and India followed the Soviet model of capital accumulation, which did not make sense in these high-population countries. Promotion of heavy industry, with little attention to manufacturing and light industry, did not foment growth as policy makers desired. It was not until both governments (at different times) opened up to some trade and reduced barriers to entry into labor or human capital industries that reform was truly successful.

All three development trajectories involved selective liberalization in particular industries. Japan's government gave priority to the export of heavy industrial goods, while China's gave priority at first to export of light consumer goods sent out from Special Economic Zones. India embarked on a range of gradual liberalization policies in the areas of licensing reduction, some trade liberalization, and reduced role of the state.

These initial conditions helped to shape the nature of reform policies and their resulting success. Talented reform leaders had to take into account the resources and circumstances of each nation in order to create policies that would function well in each environment. Policy makers built 
on initial conditions to gain acceptance as well as to ease the transition from low levels of development to industrialization and modernization.

Next, we examine the reform process from a general perspective, in each country in turn. We begin with the case of Japan, then turn to China and India.

\section{Japan}

Japan began its growth trajectory during the Meiji era, 1868-85. Western Europe and the United States had, at this time, just completed the industrialization process. Feudal institutions of the previous period (Tokugawa) were eliminated, reducing privileges based on title and increasing privileges based on merit. Monetary and fiscal systems were modernized, and people were educated to use modern technology. The Tokugawa fiscal system had many tax rates (based on the rice tax), so the Meiji government implemented a modern form of taxation on land, which was not subject to harvest. This also made the taxpayer the legal owner of the land (Yoshihara 1994).

The Meiji government also centralized the issue of money, and made uniform measurement units (Yoshihara 1994). The decimal system was implemented and the yen was used as the basic monetary unit (gold and silver coins were previously used). The Meiji government also built up the country's infrastructure. In 1869, the government began constructing railways. Railway mileage increased rapidly, and sea transportation was modernized by importing steamships from the West. The network of communications was built up, with the introduction of postal and telegraphic services.

Joint stock companies were formed in the fields of transportation, finance, and land reclamation (Yoshihara 1994). Machines began to be used widely, as machines were imported from the West and foreign technicians were invited to Japan. The government was able to operate mines and factories in textiles, metals, cement, glass, and shipbuilding. Spinning was given first priority for modernization. The rise of the textile industry increased Japan's exports to China. The Japanese textile industry phased out imports of textiles.

Development also took place in agriculture, with an increase in the production of rice due to the introduction of new strains which were responsive to the application of fertilizer and were resistant to cold (Yoshihara 1994). Silk was also an important good. With development, more and more people moved from the agricultural to the non-agricultural sector. Hence an increasingly large percentage of the population was forced to purchase food. Increased production of tea and raw silk made it possible 
to earn enough foreign exchange to buy machinery and industrial raw materials from abroad.

Heavy industry increased between 1912 and 1936 (Yoshihara 1994). Over this period, Japan became less dependent on agriculture since the colonies it had acquired during war, Taiwan and Korea, became Japan's food suppliers. There was a rapid increase in cotton fabric production, a light industry, while armaments production, a heavy industry, increased as well. Japan was producing weapons for other countries in World War I.

After World War I (1918), the West had reduced economic capacity, and Japan experienced a severe recession in the 1920s, with many bankruptcies and high unemployment. Concentration on heavy industry and finance increased (Yoshihara 1994). The intensification of output concentration remained for some time, with several zaibatsu, or family-controlled conglomerates, exerting large influence on the economy in the latter part of this period (1930s). The relationship between the zaibatsu and the government became very close, with the zaibatsu evolving into powerful politico-economic organizations.

Japan's economy after World War II was devastated, and the threat of famine was real (Yoshihara 1994). The Allies, who occupied Japan after the war, imposed democratic reform both politically and economically. Land was redistributed and the zaibatsu, large business conglomerates, were broken up. The US transferred technology to Japan, giving way to advances in production based on chemistry, physics, and electronics. The post-war economic system promoted free trade, which was beneficial for Japan, an exporting nation. Freer international trade strengthened internationally competitive industries and weakened uncompetitive ones, enhancing the efficiency of the economy (Yoshihara 1994).

Sustained increase in exports required that heavy industrial goods become major exports since their terms of trade were more favorable and their demand elasticity was higher than that of other goods (Yoshihara 1994). Subsidies for industrial expansion and renewal were given to encourage the introduction of more up-to-date machinery and technology in heavy industry. To protect the companies which were producing heavy industrial goods, the government restricted imports of these goods through foreign exchange control.

By 1960, the government's industrialization policy began to show returns (Yoshihara 1994). Heavy industry had become internationally competitive in steel, ships, and radios, and was becoming the propelling force of Japanese exports. By the mid-1960s, motor cars, synthetic fibers, and new electronic products like tape recorders and TV sets had joined the list of major exports. Textile products declined in importance in the face of growth in heavy industry. 
By 1972, Japan had become the world's largest producer of synthetic fibers, rubber products, pig iron, and passenger cars, and Japanese industry had become one of the most advanced in the world (Yoshihara 1994). Machinery and equipment replaced industrial materials as Japan's leading industrial sector in the mid-1970s (Yoshihara 1994). The growth of electrical machinery, including electronics, was spectacular. In the early 1980s, integrated circuits, videotape recorders, and computers became the growth points of the industry. The shift overall was toward high-value-added, lowenergy-using industries. Cars became Japan's major export item.

\section{China}

The Chinese economy, as rational as it may appear after reform was begun, was led not by an external economic theory, but by the ideology of a single man. Transformed into an ideology-centered state by Mao Zedong, a cult of personality surrounded Chinese leadership well into reform. For the lacuna that Mao left when he died in 1976, a leadership such as Deng Xiaoping's, embodied in one man, was arguably necessary.

China's leadership under Mao was effectively a dictatorship. There can be no other explanation for the continuing dedication of civil servants to Mao's changing, sometimes irrational, ideology other than the idea that Communist Party officials swore allegiance to Mao himself. This can be illustrated in multiple ways; the Great Leap Forward and the Cultural Revolution, in which millions of people died, have been viewed by Maoist scholars as demonstrations of a Leftist turn in Mao's ideology which were not in line with the common view of Mao Zedong Thought (Womack 1986). And yet these schemes were carried out by committed government officials who upheld the cult of personality, whether for fear of reprisal if they diverged from doing so, or from a true belief in the system.

By 1978, China was clearly ready for a new direction but hungry for a new, powerful leader. At this time, the rest of the world was about to embark on a period of neoliberalism and high consumption. China wanted to join in. Given the eagerness that the Chinese showed to break with the past and promote growth rather than economic stagnation, Deng Xiaoping, who was previously purged from the party as an opponent of the Cultural Revolution, represented opposition to the anti-capitalist movement of his predecessor, and emerged as a leader during the meeting of the Third Plenum in December 1978. Deng Xiaoping, although far less dictatorial than Mao Zedong, was followed with much of the same exuberance and devotion that Mao had experienced in his cult of personality.

Deng Xiaoping Theory guided the Chinese economy during the first phase of reform. This was entirely separate from economic development 
theory of the day. The Theory advocated pragmatism and truth-seeking in its objective of joining a market economic system to a socialist political system. It was unrelated to accumulation of capital, which the Maoist economy had focused on, and it broke with rising neoliberal attitudes among Western nations that emphasized rapid liberalization of trade and financial channels.

Deng and other policy makers increased China's competitiveness in incremental five-year plans that carefully accommodated prior policy successes. The Chinese economy was first reformed to continue producing for the planned economy, while beginning to produce for the market, outside of the plan (Naughton 2007). The plan was aimed to decline over time in a process called "growing out of the plan." Market forces were allowed to arise slowly, with market prices increasingly permitted.

Quite notably, significant reform began in the countryside, with the implementation of the household responsibility system, which allowed famers to contract individual plots of land from the collective. The household responsibility system was initiated by farmers in Anhui province, and officially adopted by the Fourth Plenum of the Eleventh Central Committee of the Communist Party in September 1979 (Chow 2007). Traditional production, rather than collective production, re-emerged, and greatly enhanced productivity in the agricultural sector. Farmers were allowed to raise chickens, pigs, and ducks, and to sell on the market food produced in excess of the target. Township and village enterprises, rural industrial enterprises controlled by local governments, were allowed to produce for the market.

State-owned enterprises, formerly fully controlled by the state, underwent a process of incentivization through profit retention and reward for work effort. The process was begun in 1978 with six pilot enterprises in Sichuan province, and was spread to 6600 industrial enterprises by June 1980 (Chow 2007). In 1987, the state-owned enterprises were contracted to pay the government a fixed tax rather than surrendering most of their proceeds. This helped to free the enterprises from direct financial obligation to the central government. During the 1980s, however, policy makers continued to control many aspects of these firms; control was lessened gradually, and more extensive privatization of state-owned enterprises would occur more than a decade later.

Price reform was an essential part of reform that began in October 1984, with the decision of the Central Committee of the Communist Party to begin to decontrol prices gradually. Part of the output produced was sold at controlled prices, while additional output above the target could be sold at prices determined by the market. This was part of the dual track system. Importantly, food prices did not rise even after they were decontrolled due 
to the large rise in agricultural output as a result of the household responsibility system (Chow 2007). Low and very gradually rising housing prices in urban areas maintained social stability until the end of the 1990s, when urban housing was mainly privatized.

The banking system was entirely altered from a deposit-taking monobank operating as the People's Bank of China, to a central bank with specialized banks underneath it. The People's Bank was given more independence as a central bank in the 1990s, and loans were increasingly extended to businesses outside the state-owned enterprise sector.

Exports through Special Economic Zones were permitted and consumer goods were increasingly produced. The Special Economic Zones were coastal areas in which foreign enterprises were given tax breaks and other incentives to establish factories to produce goods for export. The number of Special Economic Zones expanded through the reform period, and were a key element in attracting foreign capital.

The reform process was increased in the 1990s, as Deng Xiaoping became unable to participate in politics, and focused on some sectors over others. The nature of the reform process turned toward further trade and financial liberalization of the economy. Zhu Rongji became Premier in 1998, but even as Vice-Premier he was heavily involved in the direction of economic reform. Reform in the 1990s included market reunification, producing more extensively for the market (Naughton 2007). Macroeconomic austerity, including tighter fiscal and monetary policy, and banking restructuring were also key elements of reform in the 1990s.

Although during the Maoist era "privatization" was a dirty word, it eventually was necessary to increase economic productivity. The privatization process of the 1990s resulted in mass lay-offs from state-owned enterprises. Privatized state enterprises were then listed on the stock exchanges, although the majority shareholder often continued to be the state. Despite the fact that it was a big step toward reduced direct state intervention in the economy, privatization was unpalatable to former employees and resulted in widespread demonstrations among those let go. Because of large-scale lay-offs, the 1990s have often been referred to as a period of "reform with losers."

Many state-owned enterprises were shut down over this period of "grasping the large and letting the small go." This meant that the central government forced smaller enterprises to change ownership or close down. This was a period of employment churning and a large change in the economic mentality in an embrace of market forces.

China's accession to the World Trade Organization underscored its importance in the global economy. Trade barriers were lowered and competition increased. China's trade cooperation with other nations in the 
region rose and helped to sustain its status as the "factory of the world." Growth seemed limitless in the early 2000s.

\section{India}

India attempted to reform immediately after independence in 1947 under a planned economy with a heavy emphasis on heavy industry but, as in China under Mao, was unsuccessful in this approach. Unlike China, India neglected agriculture until it was faced with famine in the 1960s. The government realized that low productivity in agriculture was a result not of ignorance, but of real constraints, and encouraged the implementation of high-yielding seed varieties and better fertilizer with the Green Revolution (Chai and Roy 2006). Although helpful, the lack of proper irrigation, the third leg of the Green Revolution triad, caused the Indian agriculture sector to continue to suffer. Low growth in the 1970s perpetuated India's stagnation.

In the 1980s, India increased market orientation and implemented some deregulation policies, improving the growth of the economy (Chopra et al. 1995). Partial trade liberalization and loosening of domestic industrial controls were carried out. Expansionary fiscal policies stimulated domestic demand as well. This was successful in bringing about some growth. Growing government expenditures and falling revenues, however, contributed to the economic crisis India experienced in 1991 that began India's current trajectory of reform.

India's reforms accelerated in the 1990s. The reforms were stimulated by a balance-of-payments crisis and a subsequent IMF package that required fiscal tightening (Panagariya 2002). The crisis, coupled with the decline of the Soviet Union, an important trading partner, and with increasing globalization and subsequent availability of portfolio investment and world trade, led to a dramatic opening up of the country (Kohli 2006). The collapse of the Soviet Union, contrasted with the growth of China, set the stage for India's dramatic reforms, as the country turned away from extensive government intervention to a more market-based economy (Singh and Srinivasan 2006). The fast pace of the globalization process in the rest of the world also put pressure on India to change its economic circumstances. The development of a need in the rest of the world for cheap goods and services also influenced India's reform trajectory.

Many of the high-impact reforms were carried out at this time under the New Economic Policy of July 1991, including the abolition of industry licensing, implementation of policies to attract foreign portfolio investment and foreign direct investment (FDI), and reduction of customs duties to improve the export outlook (Acharya 2002). In addition, the role of the 
public sector was reduced, restrictions on new manufacturing projects were loosened, and industrial location policy was liberalized (S. Mitra 2008).

Heavy industry, heavily monopolized by the state prior to reform, and other industries, subject to industrial licensing or reserved for small enterprises, were decontrolled. The number of government-controlled industries was reduced over time to three: defense aircraft and warships, atomic energy generation, and railway transport (Ahluwahlia 2002). Imports, formerly subject to tariffs as high as 400 percent, became more commonly accessible (Panagariya 2002). In addition, private sector firms were allowed to invest in industries previously reserved for the public sector, and limits on foreign equity holdings were increased from 40 to 51 percent for many industries (Athreye and Kapur 2006).

Later, the number of industries requiring licensing decreased even further, and infrastructure industries such as telecommunications opened up to the private sector, including foreign ownership (Athreye and Kapur 2006). Tariffs were further reduced, and the list of freely importable goods was expanded. The pricing of pharmaceuticals was deregulated. A depreciated exchange rate was maintained to encourage exports, and exporters gained better access to foreign exchange (Wignaraja 2011). The dual exchange rate was unified and the current account became convertible. Impressively, Indian industries responded to the measures with enthusiasm, upgrading technology, improving managerial efficiency, and engaging in increased competition (A. Mitra 2008).

India's banking system was also reformed, removing interest rate controls, introducing capital adequacy requirements, and allowing expansion of private and foreign banks (Ahluwahlia 2002). The government continues to attempt to reduce its ownership stake in the banking system. A new bankruptcy law has also been introduced to allow creditors to enforce their claims.

In 2003, a Special Economic Zones (SEZ) Act was passed to promote exports (Wignaraja 2011). These SEZs offered financial incentives to attract foreign corporations. The US, after Mauritius, is the largest supplier of inward FDI into India. FDI brought with it new technologies, skills, and marketing connections. However, inward FDI in India has been used to produce goods for the domestic economy and has not been used to produce manufactured goods for the world, as it has in China. Indian outward investment increased before the global crisis in the areas of information technology, pharmaceuticals, petroleum and natural gas, consumer goods, and steel (Wignaraja 2011). Most outward FDI was invested in the US and the UK.

Growth increased after 2003 as domestic industry restructured and corporate profits increased. The financial sector expanded and infrastructure 
was somewhat improved. Education and health programs reached more individuals. India became a star performer in terms of economic growth.

\section{THE POLITICAL ECONOMY OF REFORM}

The political economies of reform in China, India, and Japan are vastly different from one another. The development of these economies has changed some views on the role of the state toward a more pluralistic approach. From a perspective in the 1950s and 1960s of viewing state intervention as essential, to a perspective in the 1980s and 1990s of viewing markets as essential to development, economists now generally accept that different combinations of markets and state are possible in development.

How did reform come about politically in China, India, and Japan? The political climates during the creation of the reform period differed in the three nations, but all had the effect of prompting reform, out of political and economic needs. While the histories of all three countries have in a sense defined their current political economies, their histories have greatly diverged in that sense. China has, for the most part, been in control of its destiny through history, while India was only clearly defined under British colonial rule (Desai 2003). Japan itself was a colonial power in recent history. India's economy was left in a weakened state as a result of colonial rule, since the British ruling class set up institutions that allowed those at the top to gain financially from economic activity while neglecting to provide social services for the poor. Society was thus quite stratified, only the elite were educated, and the state was mainly a vehicle for the military, policy, and justice systems, as tax revenues were kept minimal (Maddison 1971). Left to a large degree unmolested by foreign powers at the outset of reform, both China and Japan had a strong sense of shared culture among the citizenry that propelled forward the acceptance of economic reforms.

Economic histories also diverged in that China's and India's pre-reform periods focused on industrialization and capital accumulation, while Japan's pre-reform period failed to focus on either industrialization or other elements of economic growth. China's and India's tendency during the post-World War II period to follow the socialist pattern of physical capital accumulation, however, did not result in growth, such that these economies, like Japan's, lacked sources of growth at the outset of reform.

In Japan, restoration of Meiji rule occurred after the Tokugawa Shogun's forces were defeated. Although the Shogun had resigned the year before, he had remained powerful and had to be physically defeated in order to restore direct imperial control. Young samurai were hostile to the Tokugawa Shogun, as it was felt that Japan was increasingly behind the 
rest of the world in the industrialization process. The Tokugawa regime's prohibition of trade with Western nations prevented merchants from developing a potentially profitable export sector. Mounting opposition to the government, along with famines that resulted in peasant uprisings, set the stage for the Tokugawa regime to be defeated.

The Tokugawa regime, however, had not been without its successes. During the seventeenth and eighteenth centuries, the Tokugawa regime had seen increased agricultural production, including in staple and cash crops, and in commerce and manufacturing (History Channel 2014). Urbanization increased and peace prevailed. Urban commercial activities brought economic participation from all ranks of individuals, including townspeople themselves and not just the nobility, and increased demand for agricultural products from the countryside.

The Tokugawa Shogun's requirement that the feudal lords, the daimyo, reside alternately in Edo (now Tokyo) and in their own home regions resulted in the construction of an extensive road system, which would provide infrastructure necessary for enhanced growth in the Meiji period, and help to unite the country under a sense of shared culture, with socialization at a national level occurring in the capital of Edo (Pyle 1996). Large family enterprises grew during the Tokugawa period and became the precursors to the zaibatsu, or large industrial enterprises, during the Meiji period.

It was when the Tokugawa regime became unable to satisfy the economic needs of the peasantry, the merchant class, and the samurai that a strong sense of dissatisfaction emerged, opening the way for the Meiji Restoration to take place. Satsuma and Choshu were the two domains that overthrew the Tokugawa Shogunate, and the Meiji period thus began as an alliance between those two regions. The Charter Oath was laid out on April 6, 1868 to establish that feudal institutions would be dissolved, and that assemblies would create policies based on public discussion. In 1889, Japan's first constitution was introduced and a parliament, or Diet, was established, with the Emperor as the leader.

In China, reform occurred only after Mao Zedong died, and after a short period, Deng Xiaoping took power. Deng Xiaoping was more popular than Mao's chosen successor, Hua Guofeng, and was supported by the Communist leadership, which felt that China was economically lagging behind the rest of the world. As in Japan, his economic policies and attitudes had the support of the leadership. China was also moving out of a period of brutality and particularly weak economic performance, and many people were discontented with their lives.

The Cultural Revolution had taken place between 1966 and 1976. Led by the so-called "Gang of Four," the aim of this revolution was to rout 
out capitalist and traditional thinking and to reinforce Maoist doctrine. During this period, millions of Chinese citizens were persecuted and even killed. The psychical damage done to the citizenry during this period was considered a setback for the Communist Party; by the time of Mao's death, ordinary citizens and many party members were hoping for a period of clemency.

This occurred under the leadership of Deng Xiaoping, who had himself experienced life as a target during the Cultural Revolution. Despite that, Deng remained in the political realm and stressed national unity as a precursor to economic growth. After Mao's death, Deng criticized the Cultural Revolution and brought about the "Beijing Spring," allowing open dissent toward the Cultural Revolution (PBS Newshour 2009). The positive energy that Deng carried into the reform period propelled his popularity as a de facto reform leader.

India had begun some reforms through the 1980s, but an economic crisis speeded up the process. In order to avoid defaulting on its debt, India requested financial assistance from the IMF. The IMF extended a $\$ 2.2$ billion loan, with additional requirements for economic restructuring. The Prime Minister, P.V. Narasimha Rao, who took over in June 1991 at the peak of the crisis, took seriously the task of economic restructuring and reform.

Rao came to office at a time of political chaos; Rajiv Gandhi had just been assassinated by a Sri Lankan terrorist (Aiyar 2011). However, although Prime Minister Rao is not as celebrated as Nehru or other Indian leaders, he had the foresight to induct an economist rather than a politician into his cabinet as Finance Minister (Wadhva 2004). This Finance Minister was Manmohan Singh, who would later himself become Prime Minister. Prompted by IMF conditionality in response to a government bailout, the Rao administration implemented some major changes into India's economy, shifting toward an export-oriented model.

Vested interests were not unanimously approving of the aggressive pace of reforms, so two years into the reform trajectory, the Rao administration slowed down its rate of implementation (Wadhva 2004). At this time, since economic stability had been greatly improved, the Rao government also came out with its own vision for reform. India's economy began to grow at an annual rate of 7.5 percent, and this lasted between 1994 and 1997. The economy had made an impressive turn toward market institutions.

\section{Effects of Reform}

As Wignaraja (2011) points out, China was much "swifter, more coordinated, and more credible in its overall reform process than India." China's 
five-year plans reflected streamlined goals for the outcomes the leadership wanted to see take shape. China introduced an open-door policy in 1978, while India opened up trade after 1991. China was quick to adopt a growth strategy, that of export-oriented manufacturing, while India was slow to find its niche in service exports.

Japan's reform process was arguably more coordinated than that of China; it necessarily had to be so since it covered an entire century. And it is the ultimate success story, transforming a poor, developing country with few natural resources and relatively low population and population growth into a modernized economy with a very high standard of living.

Growth was a focus of reform in all three countries, and the status of social service provision has been wildly divergent as a result. In China, social services such as health insurance, unemployment provisions, and social security benefits have lagged behind since reform began and particularly since the 1990s. Rural Chinese suffered greatly due to the lack of access to medical care. Individuals were unable to pay out of pocket for their health care. The New Cooperative Medical Scheme has sought to cover all individuals for basic medical services, but has been unable to cover services for catastrophic illnesses (Zhang et al. 2010). Unemployment benefits began in 1986 for urban workers if the state-owned enterprise they worked for declared bankruptcy (Duckett 2003). In 1999, unemployment insurance participation became mandatory for all urban firms and their employees. Employees who were laid off from state-owned enterprises were eligible for a living allowance for three years, after which time they could be eligible for unemployment benefits for two years if the employer had contributed to the unemployment fund for that purpose. Currently, workers are eligible for unemployment insurance or one-off redundancy payments alone. Pensions for urban workers were developed, but pensions for rural workers arose only in wealthy rural areas. The National Social Security Fund, created in 2000, strove to provide income where pensions could not. The fund is invested in global capital markets and seeks to alleviate the burden of the aging population which was entirely on the shoulders of the government, by sharing it between the government, employers, and employees (Leckie 2009).

India has fallen behind greatly in social services. Sixty-eight percent of global leprosy cases are in India (Kapila 2008b). India also has an above-average incidence of nutrition-related illnesses. Public expenditure is extremely low, at 0.8 percent of GDP. Although national health care has expanded in quantity, quality has suffered. Social security is in a somewhat better position: the National Social Assistance Programme was introduced in 1995, providing social assistance in the case of old age, widowhood, and maternity (Justino 2003). The support is minimal, 
particularly for old age assistance (at 75 rupees a month), but it is a step in the right direction.

Japan's social services are much better developed than in India and China. Its national pension program paid out 7.8 percent of monthly wages in 2010. Those who are eligible include individuals age 65 and older with at least 25 years of contributions. An early pension may be available starting at age 60 with at least 25 years of contributions (US Social Security Administration 2012). Disability and survivor benefits are also paid out as part of the pension system. Japan also has a universal health care system that costs patients less and yet comprises a relatively low percentage of GDP.

\section{DATA TRENDS}

Next, I look at these countries from a general perspective over time. To start with, one of the most commonly used indicators of economic development and well-being is GDP per capita. Figures 1.1 and 1.2 illustrate the rate of growth in modern times of the three countries. GDP per capita increased from \$186 in China and \$229 in India in 1980, to \$2423 in China and $\$ 830$ in India in 2010. This is more than a threefold increase for India and an elevenfold increase for China. GDP per capita in Japan increased from $\$ 7241$ in 1960 to $\$ 39733$ in 2010, a fivefold increase. Important to

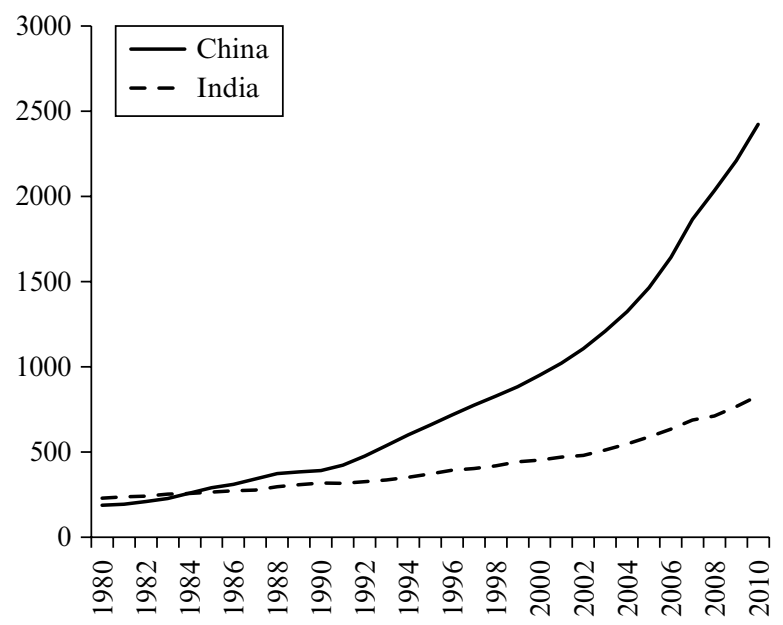

Source: World Development Indicators Database, World Bank.

Figure 1.1 China and India, GDP per capita (2000 US\$) 


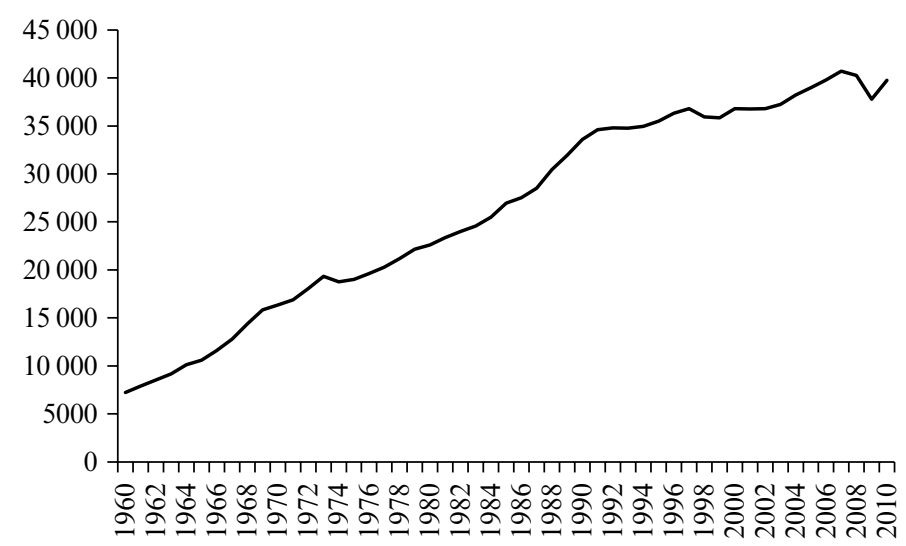

Source: World Development Indicators Database, World Bank.

Figure 1.2 Japan, GDP per capita (2000 US\$)

note is that in Japan, even during the "lost decade" and long recession of the 1990s, GDP per capita continued to rise.

The trend in exports of goods and services as a percentage of GDP was on the whole increasing in China and India between 1970 and 2010, but somewhat stagnant in Japan over this period. The Great Contraction of 2008 caused a major decline in exports toward the end of the period in all three countries (Figure 1.3).

Over the years, Japan has become a productive manufacturing nation that specializes in advanced technology for export. Japanese diversification, especially within the manufacturing sector, has produced high-quality goods such as games, computers, and cars, which have been in demand in global markets for decades. The top five export trade partners with Japan - the US, China, the European Union, South Korea, and Taiwan account for two-thirds of total Japanese exports based on World Trade Organization (WTO) statistics for 2005. Most Japanese trade today comes from its multinational corporations. In 2000, multinational firms accounted for 95.1 and 85.4 percent of its exports and imports, respectively (Kiyota and Urata 2005).

Japan also necessarily imports many goods due to its dearth of natural resources. It is dependent on overseas imported supplies of petroleum, aluminum, nickel, uranium, iron ore, and other resources. Japan imports mainly from China, the United States, Australia, Saudi Arabia, and South Korea.

China is a large exporter of manufactured goods. Most of these goods 


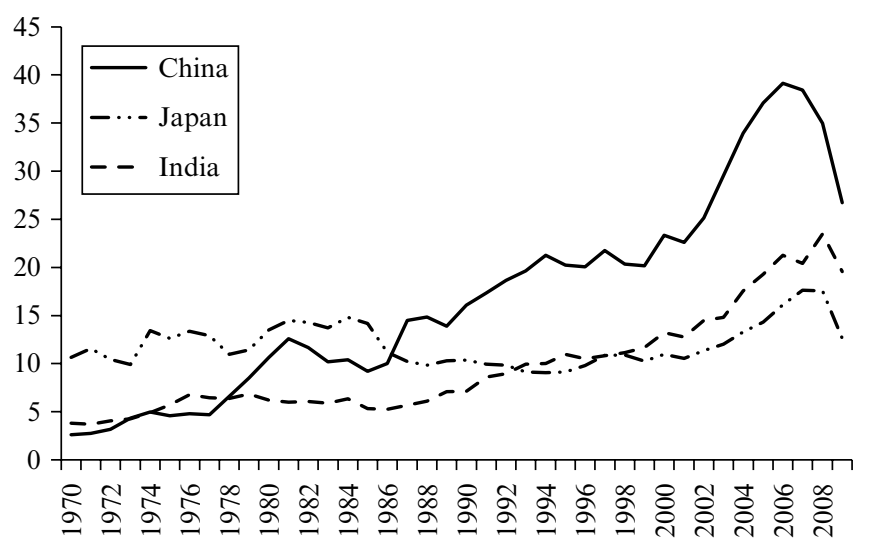

Source: World Development Indicators Database, World Bank.

Figure 1.3 Exports of goods and services (\% of GDP)

are labor-intensive, although goods for export are becoming increasingly technology-intensive. China's main trading partners are the US, Hong Kong, and Japan (US Department of State 2011b). China has become, through both exports and imports, a driver of world growth.

India's economy was closed until the 1990s, with extremely high tariffs in place. India has opened since then, with trade increasing to 35 percent of GDP in 2005, although tariffs continue to be high (World Bank 2011). Agricultural tariffs remain at around 30-40 percent, and anti-dumping measures are also used. India's main trading partners are the European Union, the United States, and China (Polaski et al. 2008).

As in many other countries around the world, China, India, and Japan improved in terms of health indicators over the modernization period. Japan's infant mortality rate (deaths per 1000 live births) declined from 30 to 2 between 1960 and 2010 (Figure 1.4); while China's declined from 62 in 1975 to 16 in 2010 (Figure 1.5); and India's declined from 114 in 1975 to 48 in 2010 (Figure 1.5).

Gross fixed capital formation as a percentage of GDP increased in China and India between 1965 and 2010, and declined over the period in Japan (Figure 1.6). 


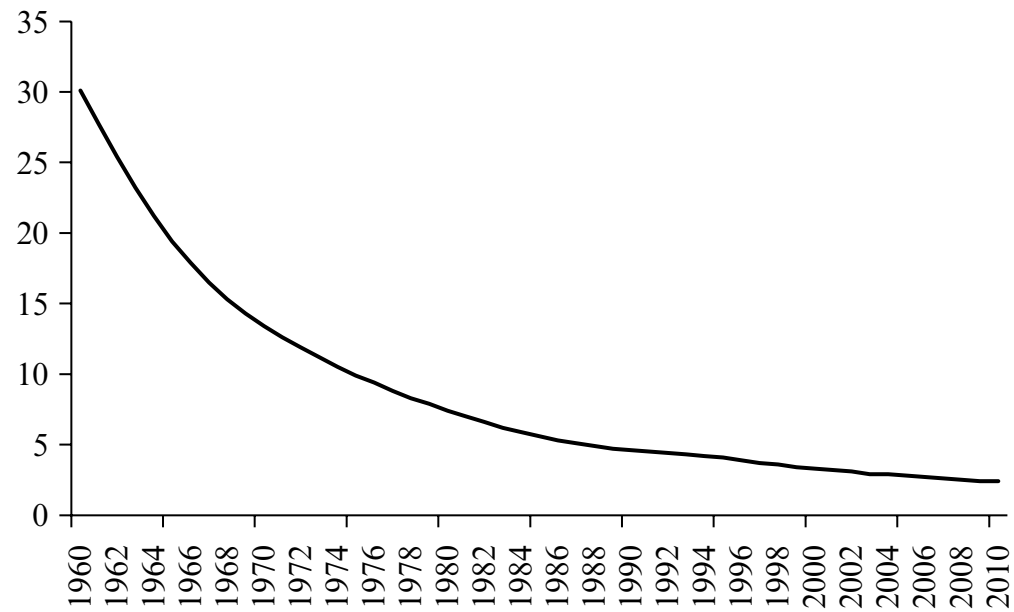

Source: World Development Indicators Database, World Bank.

Figure 1.4 Japan's infant mortality rate (per 1000 live births)

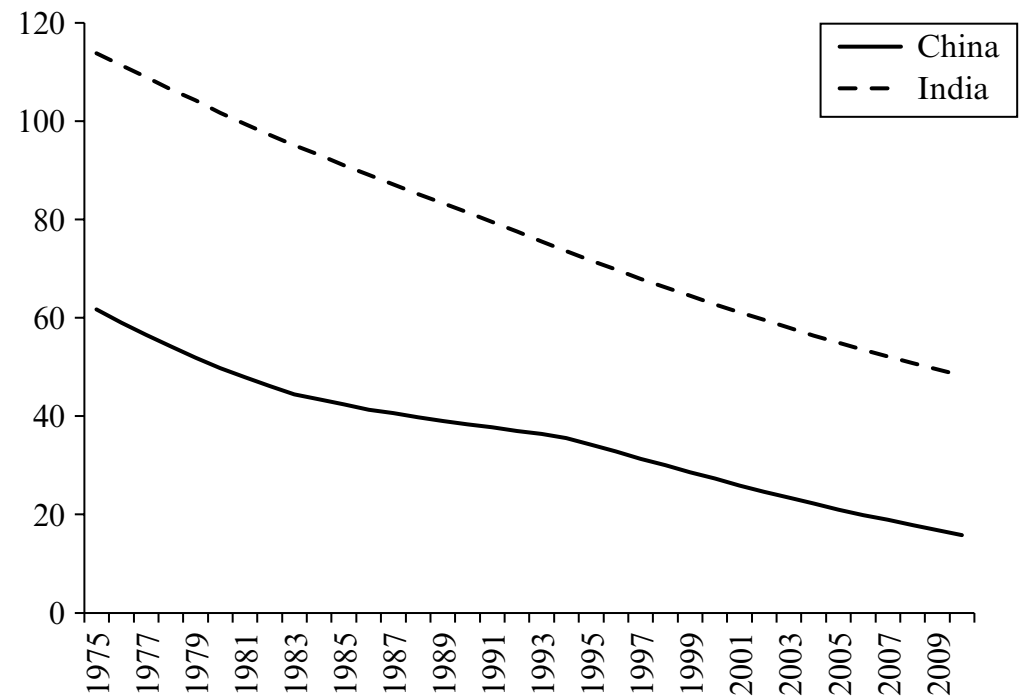

Source: World Development Indicators Database, World Bank.

Figure 1.5 China's and India's infant mortality rate (per 1000 live births) 


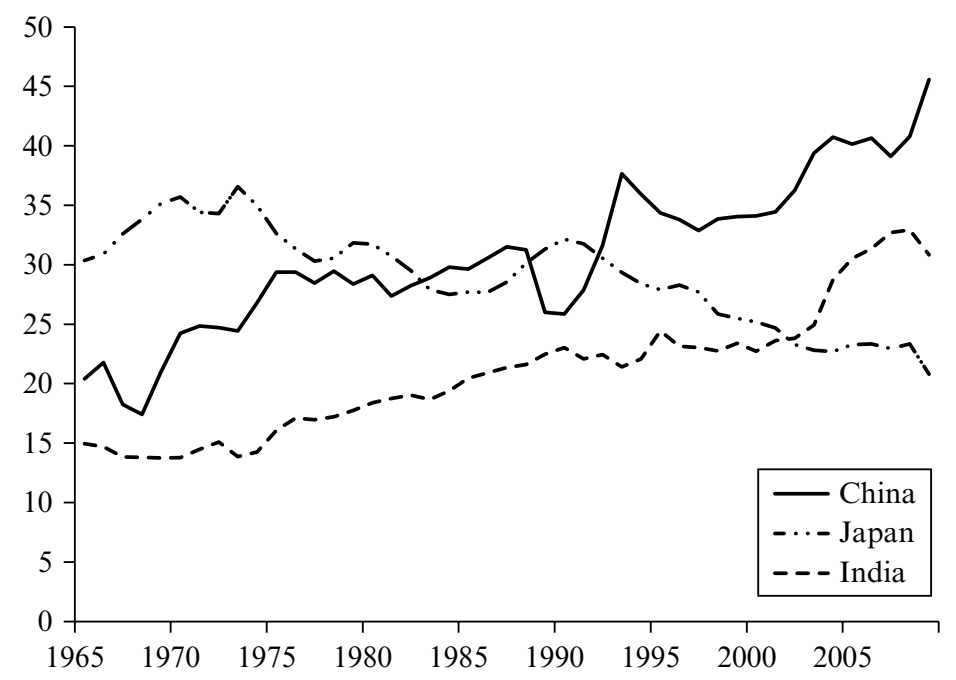

Source: World Development Indicators Database, World Bank.

Figure 1.6 Gross fixed capital formation ( $\%$ of GDP)

\section{POVERTY LEVELS}

Poverty levels declined in China, India, and Japan as economic development came about. Poverty declined as better jobs arose, medical technology and services progressed, and nutrition improved. Explicit poverty-oriented social welfare programs also reinforced this trend. China's percentage of extreme poverty declined to 9.2 percent of the population by 2010, while India's fell to 32.7 percent by 2010 (Figure 1.7).

In Japan, the poverty rate at under 200 yen was 17.7 percent of all households in 1930 (Chūbachi and Taira 1976). The poverty rate at under 100000 yen in 1968, a comparable level almost 40 years later, was 14.4 percent. Therefore while poverty was not exceedingly high in Japan in the early stages of its reform period, it did not decline as much as one might expect, as in the case of China.

\section{BOTTOM LINE}

Development and reform unfolded in China, India and Japan at different times, incorporating distinctive institutions. Unique political systems and 


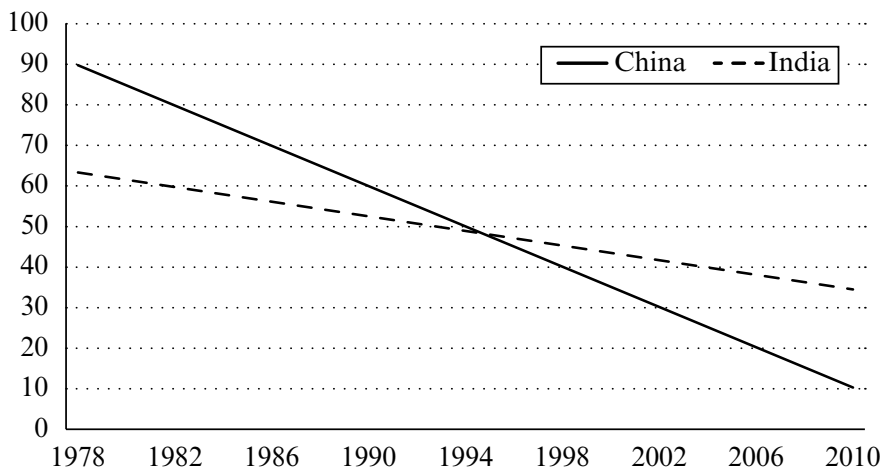

Source: World Development Indicators Database, World Bank.

Figure 1.7 Poverty headcount ratio trend line at \$1.25 per day, China and India (\% of population), 1978-2010

initial economic conditions gave rise to individual reform paths. China, India and Japan grew rapidly after concerted reform efforts under different internal and external circumstances. Their reform trajectories emphasized using their strengths, or comparative advantages, in order to foment growth. All three countries worked to build human capital, financial systems, infrastructure and trade, with varying degrees of progress and success.

In this book, we discuss the evolution of development in China, India, and Japan. Chapter 2 explores development theory and its associated modeling. Chapters 3, 4, and 5 look at the development trajectories of Japan, China, and India, respectively. Chapter 6 analyzes the status of poverty and inequality in these countries. Chapter 7 focuses on urbanization and migration patterns within China, India, and Japan. Population, human capital, and labor are described in Chapter 8; and the impact of reform on the environment in Chapter 9. Chapter 10 examines the trade status of these nations; and Chapter 11 concludes with a discussion of the economic future of China, India, and Japan.

\section{DISCUSSION QUESTIONS}

1. What can be said about the time period in which reforms began in China, India, and Japan?

2. Did the external context (global conditions) play a part in the success of reforms and if so, how? 
3. How did the reform trajectories of Japan, China, and India differ from one another?

4. In what ways were the reform trajectories of Japan, China, and India similar?

5. What are some necessary initial conditions for reform? 